\title{
Effect of selected local medicinal plants on the asexual blood stage of chloroquine resistant Plasmodium falciparum
}

Mohd Ridzuan Mohd Abd Razak*, Adlin Afzan, Rosnani Ali, Nur Fasihah Amir Jalaluddin, Mohd Isa Wasiman, Siti Habsah Shiekh Zahari, Noor Rain Abdullah and Zakiah Ismail

\begin{abstract}
Background: The development of resistant to current antimalarial drugs is a major challenge in achieving malaria elimination status in many countries. Therefore there is a need for new antimalarial drugs. Medicinal plants have always been the major source for the search of new antimalarial drugs. The aim of this study was to screen selected Malaysian medicinal plants for their antiplasmodial properties.

Methods: Each part of the plants were processed, defatted by hexane and sequentially extracted with dichloromethane, methanol and water. The antiplasmodial activities of 54 plant extracts from 14 species were determined by Plasmodium falciparum Histidine Rich Protein II ELISA technique. In order to determine the selectivity index (SI), all plant extracts demonstrating a good antiplasmodial activity were tested for their cytotoxicity activity against normal Madin-Darby Bovine Kidney (MDBK) cell lines by 3-(4, 5-Dimethylthiazol-2-yl)-2, 5-diphenyltetrazolium bromide (MTT) assay.

Results: Twenty three extracts derived from Curcuma zedoaria (rhizome), Curcuma aeruginosa (rhizome), Alpinia galanga (rhizome), Morinda elliptica (leaf), Curcuma mangga (rhizome), Elephantopus scaber (leaf), Vitex negundo (leaf), Brucea javanica (leaf, root and seed), Annona muricata (leaf), Cinnamomun iners (leaf) and Vernonia amygdalina (leaf) showed promising antiplasmodial activities against the blood stage chloroquine resistant $P$. falciparum $\left(\mathrm{EC}_{50}<10 \mu \mathrm{g} / \mathrm{ml}\right.$ ) with negligible toxicity effect to MDBK cells in vitro (SI $\geq 10$ ).

Conclusion: The extracts belonging to eleven plant species were able to perturb the growth of chloroquine resistant $P$. falciparum effectively. The findings justified the bioassay guided fractionation on these plants for the search of potent antimalarial compounds or formulation of standardized extracts which may enhance the antimalarial effect in vitro and in vivo.
\end{abstract}

\section{Background}

Malaria is one of the major public health problems in many tropical regions, including Malaysia. The resistance Plasmodium falciparum to common antimalarial drugs such as chloroquine, sulfadoxine-pyrimethamine [1-3] and artemisinin [4] have been reported. In response to this situation, as recommended by World Health Organization (WHO), Malaysian government has changed its first line antimalarial drug regimen to artemisinin-based combination therapy (ACT) such as the use of fixed dose artemether-lumefantrine combination (Riamet ${ }^{\circ}$ ) in the

\footnotetext{
* Correspondence: eezoo79@gmail.com

Herbal Medicine Research Centre, Institute for Medical Research, Jalan Pahang, 50588 Kuala Lumpur, Malaysia
}

treatment of uncomplicated falciparum malaria (National Antibiotic Guideline 2008, Ministry of Health, Malaysia). However, the ability of the malaria parasite such as $P$. falciparum to develop and become resistant to ACT in the future cannot be denied [5-9]. Therefore, discovering new antimalarial drugs is a priority in the health sector. The challenges in malaria drug discovery are to find safe, cheap and effective antimalarial agents.

Plants have always been the main source for the search of new antimalarial drugs. Until the year of 2003, 1277 plant species from 160 families have been published by 33 tropical countries for their use in treatment of malaria and fevers [10]. In Peninsular Malaysia, about 21 plant species are used by the locals as traditional medicine for malaria treatment [11-13]. So, it is of pivotal to 
know the potential ingredients or candidates which play a major role in killing the malaria parasites. Thus, screening the plant extracts for antimalarial properties prior to bioassay guided fractionation and potent compound isolation is important.

Research on the effectiveness of medicinal plant extracts in inhibiting the growth of malaria parasite has been extensively studied worldwide. One good example is Artemisia апnиa where whole leaves extract of this plant has exhibited better antiplasmodial activity as compared to its isolated compound, artemisinin $[14,15]$. This shows that there are other unidentified compounds still remain in this plant.

Many of medicinal plants which grow in Malaysian soil have been reported by the local scientists for their antiplasmodial activities in vitro and in vivo (Table 1). In this study, another 14 selected Malaysian medicinal plants (Table 2) with traditional claims were screened

Table 1 The list of Malaysian medicinal plants with potential antimalarial properties

\begin{tabular}{|c|c|c|c|}
\hline Plant species & Local name & Plant part & References \\
\hline Agathis borneensis & Raja Kayu & Leaf & [17] \\
\hline Alpinia galanga & Lengkuas & Rhizome & [18] \\
\hline Alstonia angustiloba & Akar Lumut & Leaf & [19] \\
\hline Alyxia lucida & Mempelas Hari & Leaf & [20] \\
\hline Andrographis paniculata & Hempedu Bumi & Leaf & {$[20-22]$} \\
\hline Ardisia crenata & Mata Ayam & Root & [21] \\
\hline Ardisia crispa & Mata Itik & Leaf & {$[17,20]$} \\
\hline Blumea balsamifera & Sembong & Root, Stem & [17] \\
\hline Calotropis gigantea & Rembega & Leaf & [19] \\
\hline Carica papaya & Betik & Leaf & [21] \\
\hline Cinnamomum iners & Teja Lawang & Root & [21] \\
\hline Cocos nucifera & Kelapa & White flesh & [23] \\
\hline Croton argyratum & Semangkok & Leaf & {$[17]$} \\
\hline Cryptocarya nigra & Medang & Stem & [24] \\
\hline Dyera costulata & Jelutong & Leaf & [19] \\
\hline Eurycoma longifolia & Tongkat Ali & Root & {$[25-27]$} \\
\hline Goniothalamus macrophyllus & Selada & Stem & [17] \\
\hline Goniothalamus scorthechinii & Selada Putih & Root, Stem, Leaf & {$[17,22]$} \\
\hline Gynura procumbens & Sambung Nyawa & Leaf & [28] \\
\hline Jasminum sambac & Melati & Flower & [21] \\
\hline Kopsia fruticosa & Chabai Hutan & Leaf & [19] \\
\hline Lansium domesticum & Langsat & Leaf, fruit skin & [29] \\
\hline Leuconotis eugenifolius & Cheret Murai & Bark & [30] \\
\hline Macaranga triloba & Mahang Merah & Inflorescence & [31] \\
\hline Nigella sativa & Jintan Hitam & Seed & [21] \\
\hline Ocimum sanctum & Selasih & Whole plant & [21] \\
\hline Phoebe grandis & Medang & Leaf & {$[32]$} \\
\hline Physalis minima & Letup-letup & Whole plant & [21] \\
\hline Piper betle & Sireh & Leaf & {$[33]$} \\
\hline Piper sarmentosum & Kaduk & Leaf & [34] \\
\hline Rennellia elliptica & Segemuk & Root & {$[35]$} \\
\hline Tinospora crispa & Patawali & Stem & [21] \\
\hline Vallaris glabra & Kerak nasi & Leaf & [19] \\
\hline Xylocarpus granatum & Nyireh & Bark & [21] \\
\hline
\end{tabular}


Table 2 The list of $\mathbf{1 4}$ Malaysian medicinal plants and its traditional claims and treatments

\begin{tabular}{|c|c|c|c|c|}
\hline Family & Plant species & Local name & Traditional claims by the Malays and aborigines & $\begin{array}{l}\text { Voucher } \\
\text { specimen }\end{array}$ \\
\hline Asteraceae & $\begin{array}{l}\text { Vernonia } \\
\text { amygdalina }\end{array}$ & $\begin{array}{l}\text { Pokok panjang } \\
\text { hayat, Daun } \\
\text { bismillah }\end{array}$ & $\begin{array}{l}\text { Leaf: Used as a remedy for the management of diabetes, } \\
\text { hypertension and hypercholestrolaemia. }\end{array}$ & PID231114-18 \\
\hline Simaroubaceae & $\begin{array}{l}\text { Brucea } \\
\text { javanica }\end{array}$ & Melada pahit & $\begin{array}{l}\text { Leaf: Used as a poultice for scurf, ringworm, boils, centipede } \\
\text { bites and over enlarged spleen in fever. Root: Used as a decoction } \\
\text { for colic, dysentery, fever, bodily pain and labour pain. Fruit and } \\
\text { leaf: Used as an infusion to cure malaria. }\end{array}$ & UKMB40227 \\
\hline Leeaceae & Leea indica & Mali-mali, memali & $\begin{array}{l}\text { Leaf: Used as a poultice in skin complaints caused by poisonous } \\
\text { caterpillars and body pains. }\end{array}$ & PID241114-18 \\
\hline Lauraceae & $\begin{array}{l}\text { Cinnamomun } \\
\text { iners }\end{array}$ & $\begin{array}{l}\text { Kayu manis } \\
\text { hutan, Teja lawang }\end{array}$ & $\begin{array}{l}\text { Root: Used as a decoction after childbirth, fever. Leaf: Used as a } \\
\text { poultice for rheumatism. }\end{array}$ & PID271114-18 \\
\hline Verbenaceae & $\begin{array}{l}\text { Vitex } \\
\text { negundo }\end{array}$ & $\begin{array}{l}\text { Lenggundi, } \\
\text { Lemuni hitam }\end{array}$ & $\begin{array}{l}\text { Leaf: Used as a remedy for cleansing the birth canal and increase } \\
\text { the production of milk after childbirth. }\end{array}$ & PID261114-18 \\
\hline Combretaceae & $\begin{array}{l}\text { Terminalia } \\
\text { catappa }\end{array}$ & Ketapang & $\begin{array}{l}\text { Bark: Act as astringent in dysentery Leaf: Act as a sudorific and applied } \\
\text { to rheumatic joints, used internally for headache and colic. }\end{array}$ & PID251114-18 \\
\hline Rubiaceae & $\begin{array}{l}\text { Morinda } \\
\text { elliptica }\end{array}$ & $\begin{array}{l}\text { Mengkudu kecil, } \\
\text { Mengkudu hutan }\end{array}$ & $\begin{array}{l}\text { Leaf: Added to rice for loss of appetite, taken for head ache, cholera, } \\
\text { diarrhoea and fever. Applied in a pounded condition upon the spleen } \\
\text { and wounds. A lotion for haemorrhoids and upon the body after childbirth. }\end{array}$ & MTM193 \\
\hline Annonaceae & $\begin{array}{l}\text { Annona } \\
\text { muricata }\end{array}$ & Durian belanda & $\begin{array}{l}\text { Leaf: Used as a poultice or an infusion externally for skin complaints } \\
\text { in children, and for coughs and rheumatism. }\end{array}$ & MTA174 \\
\hline Asteraceae & $\begin{array}{l}\text { Elephantopus } \\
\text { scaber }\end{array}$ & $\begin{array}{l}\text { Tutup bumi, } \\
\text { Tapak sulaiman }\end{array}$ & $\begin{array}{l}\text { Used as a decoction (leaf or root) for preventive medicine after childbirth, } \\
\text { in tonics, to drive out round worm, for coughs and veneral disease. The } \\
\text { leaf decoction used as an antihelmintic, as a diuretic and for abdominal } \\
\text { pains. The root decoction also used to arrest vomiting. }\end{array}$ & MTE174 \\
\hline \multirow[t]{5}{*}{ Zingiberaceae } & $\begin{array}{l}\text { Curcuma } \\
\text { mangga }\end{array}$ & $\begin{array}{l}\text { Temu pauh, } \\
\text { Temu manga }\end{array}$ & Rhizome: Used as stomachic and as a mixture for continuous fever. & RZ14/10 \\
\hline & $\begin{array}{l}\text { Curcuma } \\
\text { zedoaria }\end{array}$ & $\begin{array}{l}\text { Temu kuning, } \\
\text { Temu putih }\end{array}$ & Rhizome: Used in decoction as a tonic and for indigestion. & MTC0071 \\
\hline & $\begin{array}{l}\text { Curcuma } \\
\text { aeruginosa }\end{array}$ & $\begin{array}{l}\text { Temu hitam, } \\
\text { Temu erang }\end{array}$ & $\begin{array}{l}\text { Rhizome: Used as a tonic, for a cough and asthma. Externally used } \\
\text { (pounded in coconut oil) for scurf. }\end{array}$ & RZ18/10 \\
\hline & $\begin{array}{l}\text { Alpinia } \\
\text { galanga }\end{array}$ & Lengkuas & $\begin{array}{l}\text { Rhizome: Used as a decoction to cure malaria. Carminative, stomachic } \\
\text { and ointment for skin eruptions. }\end{array}$ & MTA0059 \\
\hline & $\begin{array}{l}\text { Curcuma } \\
\text { phaeocaulis }\end{array}$ & Temu merah & Rhizome: Used by the local to treat tumours & RZ19/10 \\
\hline
\end{tabular}

As referred in $[11,36]$ and Global Information Hub in Integrated Medicine (www.globinmed.com).

for their antiplasmodial activity against the malaria parasite, chloroquine (CQ) resistant $P$. falciparum (K1) in vitro by using P. falciparum Histidine Rich Protein II (HRP2) ELISA technique [16].

\section{Methods}

\section{Plant collection and identification}

All plant parts except Brucea javanica and Annona muricata were collected from the herbal garden of Herbal Medicine Research Centre (HMRC), Institute for Medical Research (IMR), Kuala Lumpur, Malaysia. Both $B$. javanica and $A$. muricata were collected from Northern part of Peninsular Malaysia, Tupah Village, Kedah andMalaysian Agricultural Research and Development Institute (MARDI), Kedah, respectively. All plants parts except B. javanica, Curcuma aeruginosa, C. mangga, C. phaeocaulis were identified and authenticated by Dr. Richard Chung Cheng Kong and deposited in the Herbarium of Forest Research Institute Malaysia (FRIM), Kepong, Kuala Lumpur. The B. javanica was identified and authenticated by Mr. Sani Miran and deposited in the Herbarium of the Universiti Kebangsaan Malaysia (UKM), Bangi, Selangor, Malaysia. The Curcuma species were identified and deposited in the Herbarium of Herbal Medicine Research Centre, Institute for Medical Research, Kuala Lumpur, Malaysia.

\section{Plant extract preparation}

The fresh plant materials (rhizome, leaf, root and seed) were cut into small pieces, dried and pulverized into powder before extraction with solvents in increasing polarity (Figure 1). The powdered materials were first 


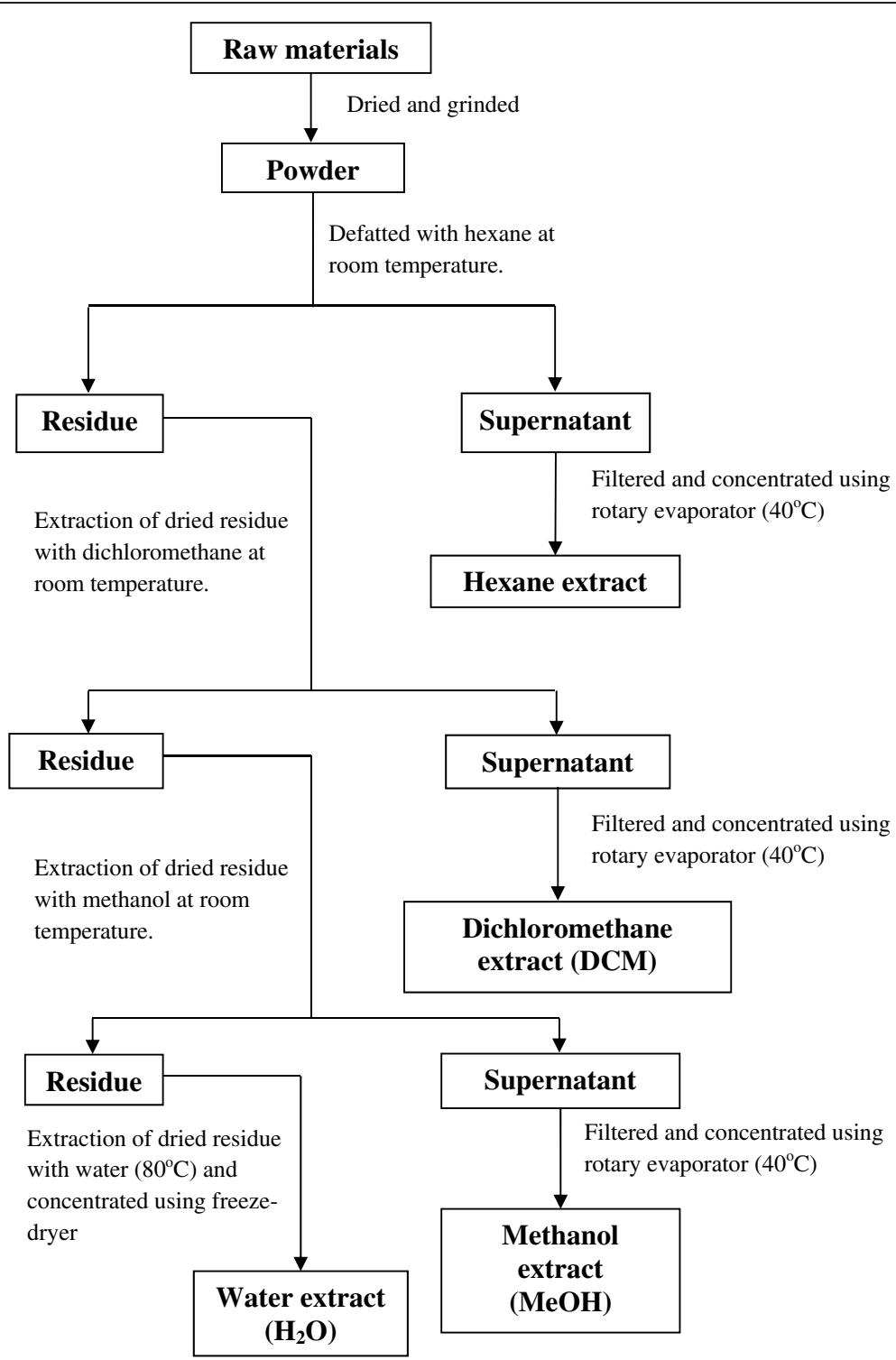

Figure 1 Procedure of plant extraction. Different part of plants was extracted sequentially by using organic solvents (DCM and MeOH) with increasing polarity.

defatted with hexane and sequentially extracted with dichloromethane $(\mathrm{DCM})$, methanol $(\mathrm{MeOH})$ and sterile deionised water $\left(\mathrm{H}_{2} \mathrm{O}\right)\left(80^{\circ} \mathrm{C}\right)$. Briefly, the resulting solutions from the first extraction using DCM were filtered through filter paper (Whatman No.1, England) to collect the supernatant from the residue. Organic supernatant were evaporated to dryness under reduced pressure with a rotary evaporator (Buchi Rotavapor R-200, Switzerland) at a temperature $40^{\circ} \mathrm{C}$. The residue was further extracted by using $\mathrm{MeOH}$ similar to the procedure that carried out for the DCM. The resulting residue was air dried and used for further extraction with sterile $\mathrm{H}_{2} \mathrm{O}$ at $80^{\circ} \mathrm{C}$. The aqueous supernatant were freeze-dried to obtain crude extracts
(Figure 1). All crude extracts (DCM, $\mathrm{MeOH}$ and $\mathrm{H}_{2} \mathrm{O}$ ) were stored at $4^{\circ} \mathrm{C}$ until used.

\section{The mammalian cells and parasites}

The CQ resistant $P$. falciparum strain, $\mathrm{K} 1$ was obtained from American Type Culture Collection (ATCC), The Malaria Research and Reference Reagent Resource Center (MR4). Madin-Darby Bovine Kidney (MDBK) cells were also obtained from ATCC. The cryopreserved parasites and cells were thawed and maintained in culture for further use in this study. Briefly, the cryopreserved parasites were thawed in waterbath at $37^{\circ} \mathrm{C}$. The thawed parasites were transferred into $15 \mathrm{ml}$ conical tubes and 
equal volume of $3.5 \%$ natrium chloride $(\mathrm{NaCl})$ were added drop wise and swirled to mix. The mixtures were centrifuged at $500 \times \mathrm{g}$ for 5 minutes and the supernatants were discarded. These steps were repeated twice before adding the complete RPMI 1640 culture medium (Invitrogen, USA) containing $25 \mathrm{mM}$ 4-(2-hydroxyethyl)-1piperazineethanesulfonic acid (HEPES), 0.2\% sodium bicarbonate $\left(\mathrm{NaHCO}_{3}\right), 0.02 \mathrm{mg} / \mathrm{ml}$ gentamycin supplemented with $10 \% \mathrm{AB}+$ human serum (Invitrogen, USA).

For MDBK cells, the cryopreserved cells were thawed immediately in the waterbath at $37^{\circ} \mathrm{C}$. The thawed cells were transferred in $15 \mathrm{ml}$ conical tubes containing $1 \mathrm{ml}$ of complete DMEM culture medium (Invitrogen, USA) containing $25 \mathrm{mM}$ HEPES, $0.4 \%$ sodium bicarbonate $\left(\mathrm{NaHCO}_{3}\right), 100 \mathrm{U}$ of Penstrep (100U penicillin and $100 \mathrm{U}$ streptomycin) supplemented with $10 \%$ fetal bovine serum (FBS). The mixtures were centrifuged at $1000 \times \mathrm{g}$, $4^{\circ} \mathrm{C}$ for 5 minutes. The supernatants were discarded. The cell pellets were transferred into $25 \mathrm{~cm}^{2}$ culture flask containing $5 \mathrm{ml}$ of complete DMEM culture medium. The suspension were mixed gently and incubated in $5 \%$ carbon dioxide $\left(\mathrm{CO}_{2}\right)$ incubator at $37^{\circ} \mathrm{C}$.

\section{In vitro culture and synchronization of $P$. falciparum}

The CQ resistant $P$. falciparum were grown by candle jar technique $\left(3 \% \mathrm{CO}_{2}\right.$ and $\left.17 \% \mathrm{O}_{2}\right)$ [37]. The culture was set up in a $25 \mathrm{~cm}^{3}$ culture flask with filtered vent and maintained in complete RPMI 1640 culture medium (Invitrogen, USA). The P. falciparum was grown in ' $\mathrm{O}$ ' type fresh red blood cell (RBC) with the initial culture started with $1 \%$ parasitemia at $2.5 \%$ hematocrit. The parasite density was monitored daily by making thin blood smears stained with $10 \%$ Giemsa solution and observed under the microscope at 1000 times magnification. When the parasitemia of the parasite culture reached approximately 5 to $7 \%$, the parasites were synchronized using 5\% sorbitol [38] and cultured for one complete cycle prior to be used in in vitro P. falciparum HRP2 assay.

\section{In vitro $P$. falciparum HRP2 assay}

All crude extracts were evaluated in vitro for their antiplasmodial activities by HRP2 assay [16,39]. The extracts were solubilised in 100\% dimethyl sulphoxide (DMSO) or sterile $\mathrm{H}_{2} \mathrm{O}\left(\mathrm{H}_{2} \mathrm{O}\right.$ extracts only) to get $5 \mathrm{mg} / \mathrm{ml}$ stocks. In preparation of extract or drug stock plates, the extracts $(5 \mathrm{mg} / \mathrm{ml})$ were serially diluted ( 2 fold dilution) to 7 point concentrations (ranging from 5 to $0.08 \mathrm{mg} / \mathrm{ml}$ ) in DMSO from well A1 to A7 in a 96 well plate. Fifteen microliters of serially diluted stock extracts were transferred correspondingly into watery plates containing $225 \mu \mathrm{l}$ of sterile $\mathrm{H}_{2} \mathrm{O}$. An aliquote of watery plates will be used in HRP2 assay.
Ring-infected RBCs with 5\% parasitemia were adjusted to $0.05 \%$ parasitemia and $1.5 \%$ hematocrit. A total of $190 \mu \mathrm{l}$ parasitized RBCs at $1.5 \%$ hematocrit were added into each well of the test plates. A total of $10 \mu \mathrm{l}$ of serially diluted extracts from the watery plates prepared above were transferred into the test plates containing parasitized RBCs and incubated in a candle jar at $37^{\circ} \mathrm{C}$ for 72 hours. The final tested concentration ranging from 16 to $0.2 \mu \mathrm{g} / \mathrm{ml}$. The final concentration of DMSO was $0.3 \%$. Chloroquine (CQ) (Sigma, USA), quinine (Q) (Sigma, USA), mefloquine (Mef) (Sigma, USA) and artemisinine (Art) (Sigma, USA) were used as standard control to validate the test. The final tested concentration for standard control ranged from 1772.6 to $27.7 \mathrm{nM}$ for CQ, 3495 to $54.6 \mathrm{nM}$ for Q, 601.3 to $9.4 \mathrm{nM}$ for Mef and 51.2 to $0.8 \mathrm{nM}$ for Art. The negative control was the infected $\mathrm{RBC}$ without extracts or with sterile $\mathrm{H}_{2} \mathrm{O}$ only. After 72 hours of incubation, the test plates were kept in $-80^{\circ} \mathrm{C}$ overnight. The plates were thawed at room temperature to lyse the infected RBCs. The activity of the parasite-extract exposure (end point) was measured by HRP2 assay. One day prior to the assay, $100 \mu \mathrm{l}$ of immunoglobulin M (IgM) capture antibody (MPFM-55A, ICL, Inc, Newberg, OR, USA) specific for P. falciparum HRP2 $(1 \mu \mathrm{g} / \mathrm{ml}$ in phosphate-buffered saline (PBS)) were added to each well of a 96-well ELISA plates (Microlon 600 , Greiner, Germany). The plates were covered and incubated at $4^{\circ} \mathrm{C}$ overnight. Following incubation, the contents of the wells were removed and the plates were washed three times with $0.05 \%$ PBS-Tween 20 (PBST). The non-binding sites of the ELISA plates were blocked with $200 \mu \mathrm{l} /$ well of $2 \%$ bovine serum albumin in PBS for 2 hours at room temperature. Following the blocking step, the ELISA plates were washed 3 times with $200 \mu \mathrm{l}$ of $0.05 \%$ PBST. Hundred microliters of the P. falciparum infected RBC lysates (freeze thawed) were transferred from the test plates into ELISA plates and incubated in humidity chamber for 1 hour at room temperature. The ELISA plates were washed as described above. Hundred microliters of the detector antibody (MPFG-55P, ICL, Inc, Newberg, OR, USA) conjugated with horseradish peroxidase $(0.2 \mu \mathrm{g} / \mathrm{ml}$ in PBS) were added to each well, and incubated in humid chamber for 1 hour at room temperature. Following a subsequent washing step similar to the above, $100 \mu \mathrm{l}$ of 3,3, 5,5;-tetramethylbenzidine (TMB) chromogen (Zymed Lab., Inc., San Francisco, CA, USA) was added to each well and incubated for $10 \mathrm{~min}$ in dark, followed by the addition of $50 \mu \mathrm{l}$ of $1 \mathrm{M}$ sulphuric acid. The absorbance was determined by using ELISA plate reader at a wavelength of $450 \mathrm{~nm}$ (FLUOstar Omega, Germany). The collected data were transferred to HN-nonLin software (malaria.farch.net) to get a $50 \%$ Effective Concentration $\left(\mathrm{EC}_{50}\right)$ value directly from the graph. 


\section{In vitro cytotoxicity assay}

The MDBK cells were maintained in complete DMEM culture medium containing $25 \mathrm{mM}$ HEPES, $0.4 \%$ sodium bicarbonate $\left(\mathrm{NaHCO}_{3}\right), 100 \mathrm{U}$ of Penstrep (100U penicillin and $100 \mathrm{U}$ streptomycin) supplemented with $10 \%$ fetal bovine serum (FBS). The cytotoxicity of the extracts were measured by 3-(4, 5-Dimethylthiazol-2-yl)-2, 5diphenyltetrazolium bromide (MTT) assay [40]. Prior to the day of test, the stock plates were prepared by serially diluting ( 2 fold dilution) the stock extracts $(5 \mathrm{mg} / \mathrm{ml})$ to 7 point concentration (ranging from 5 to $0.16 \mathrm{mg} / \mathrm{ml}$ ) with DMSO or sterile $\mathrm{H}_{2} \mathrm{O}$ (for $\mathrm{H}_{2} \mathrm{O}$ extracts only). Then, $6 \mu$ l of serially diluted stocks were transferred into 96 well plates containing $294 \mu \mathrm{l}$ of complete DMEM media (Medium plates). On the day of the test, MDBK cells were harvested and adjusted to $1 \times 10^{4}$ cell per ml. A hundred microliter of cell suspension was seeded into each well of a 96-well plate and allowed to grow overnight. Then, $100 \mu \mathrm{l}$ of test extracts taken from medium plate (as prepared above) were added to each well accordingly ranging final concentration of 0.8 to $50 \mu \mathrm{g} / \mathrm{ml}$. The final concentration of DMSO in all test was less than 1\%. All tests were performed in duplicate. The positive control for cell growth is the cell suspension without test substance while the negative control is the cell suspension with $0.05 \%$ Triton $\mathrm{X} 100$. The culture was incubated at $37^{\circ} \mathrm{C}$ in $5 \% \mathrm{CO}_{2}$ incubator for 72 hours. Fifty microliters of MTT solution (5 mg MTT in $1 \mathrm{ml}$ PBS and $2.5 \mathrm{ml}$ DMEM media) were added to each well. The plates were further incubated for 4 hours at $37^{\circ} \mathrm{C}$ in $5 \% \mathrm{CO}_{2}$ incubator. The medium was removed and replaced with $200 \mu \mathrm{l}$ of DMSO to solubilise the MTT formazan product. The solution was mixed for $15 \mathrm{~min}$ and once for $30 \mathrm{sec}$ before measuring the absorbance at $540 \mathrm{~nm}$ with a micro plate reader (FLUOstar Omega, Germany). The percentage of growth inhibition and the $\mathrm{EC}_{50}$ were estimated from a dose response curve.

\section{Determination of a selectivity index}

A selectivity index (SI), corresponding to the ratio between antiplasmodial and cytotoxic activities was calculated according to the following formula:

$$
S I_{\text {Plasmodium }}=E C_{50 \text { normal cell lines }} / E C_{50 \text { Plasmodium }}
$$

\section{Results}

Antiplasmodial activity against CQ resistant $P$. falciparum, K1 strain

A total of 54 extracts from different parts of 14 plant species (Table 2) were tested for antiplasmodial activity against chloroquine resistant $P$. falciparum by using HRP2 assay in vitro. Each part of the plants was extracted by 3 different solvents with increasing polarity (DCM-MeOH- $\left.\mathrm{H}_{2} \mathrm{O}\right)$. The discrimination of active extracts is based on ranked levels of antiplasmodial activity proposed by Rasoanaivo et al. [41]. The score for the test is classified as extracts with $\mathrm{EC}_{50}$ value less than $0.1 \mu \mathrm{g} / \mathrm{ml}$ is considered to be very good, 0.1 to $1.0 \mu \mathrm{g} / \mathrm{ml}$ is good, 1.1 to $10 \mu \mathrm{g} / \mathrm{ml}$ is good to moderate, 11 to $25 \mu \mathrm{g} / \mathrm{ml}$ is weak, 26 to $50 \mu \mathrm{g} / \mathrm{ml}$ is very weak while more than $100 \mu \mathrm{g} / \mathrm{ml}$ is considered inactive [41]. So, any extracts which exhibit an $\mathrm{EC}_{50}$ value less than $10 \mu \mathrm{g} / \mathrm{ml}\left(\mathrm{EC}_{50} \leq 10 \mu \mathrm{g} / \mathrm{ml}\right)$ is considered to have potential or promising antiplasmodial activity. The antiplasmodial HRP2 assay on the plant extracts were performed in parallel with the standard antimalarial drugs such as $C Q, Q$, Mef and Art which act as a control for the validity of the assay (Table 3). Briefly, the results of each assay were validated by determination of $\mathrm{EC}_{50}$ values produced by the standard antimalarial drugs against CQ resistant $P$. falciparum. In this study, the assay is considered valid when the $\mathrm{EC}_{50}$ value of $\mathrm{CQ}$ is more than $100 \mathrm{nM}$ [42].

The DCM, MeOH and $\mathrm{H}_{2} \mathrm{O}$ extracts from 14 plants species showed wide range of antiplasmodial activities (Table 4). Overall 41 extracts (76\%) from 13 plant species showed promising antiplasmodial activity $\left(\mathrm{EC}_{50}<\right.$ $10 \mu \mathrm{g} / \mathrm{ml}$ ) (Table 5). In detail, there are 11 extracts from 5 plant species fall within a good level of antiplasmodial activity $\left(\mathrm{EC}_{50}<1 \mu \mathrm{g} / \mathrm{ml}\right.$ ) (Table 5 ). Good to moderate antiplasmodial activities $\left(\mathrm{EC}_{50}=1.1-10 \mu \mathrm{g} / \mathrm{ml}\right)$ were detected in 30 extracts from 12 plant species (Table 5). Thirteen extracts from 6 plant species were considered weak or inactive as these extracts exhibited $\mathrm{EC}_{50}$ values of more than $10 \mu \mathrm{g} / \mathrm{ml}$ or less than $50 \%$ parasite inhibition at the highest tested concentration $\left(\mathrm{EC}_{50}>15.7 \mu \mathrm{g} / \mathrm{ml}\right)$ (Table 5). Overall, DCM and $\mathrm{MeOH}$ extracts were more active against CQ resistant $P$. falciparum with good level of antiplasmodial activity (Table 5).

\section{Cytotoxicity activity to mammalian MDBK cell line}

Forty one extracts from 13 different plant species with promising antiplasmodial activity $\left(\mathrm{EC}_{50}<10.0 \mu \mathrm{g} / \mathrm{ml}\right)$, were subjected to MTT cytotoxicity assay and tested

Table 3 Representative of in vitro antiplasmodial activity of standard drugs against $P$. falciparum K1 strain

\begin{tabular}{lll}
\hline Drugs & \multicolumn{2}{c}{$\mathrm{EC}_{\mathbf{5 0}}$ values } \\
\cline { 2 - 3 } & $\mathbf{n M}$ & $\boldsymbol{\mu g} / \mathbf{m l}$ \\
\hline Chloroquine & 149.43 & 0.077 \\
Quinine & 152.19 & 0.049 \\
Mefloquine & 23.49 & 0.010 \\
Artemisinin & 1.80 & 0.00051
\end{tabular}

Data are presented as mean of three independent experiments performed in duplicate assays.

The in vitro $P$. falciparum HRP2 assay for standard antimalarial drugs were conducted in parallel with the test plant extracts. Each of the assay were validated based on the $\mathrm{EC}_{50}$ threshold for each standard antimalarial drugs against the $P$. falciparum $\mathrm{K} 1$ strain in the lab. If the $\mathrm{EC}_{50}$ value of the standard antimalarial drugs are out of range, the test considered invalid. 
Table 4 The antiplasmodial and cytotoxicity activities of DCM, MeOH and $\mathrm{H}_{2} \mathrm{O}$ extracts of selected Malaysian medicinal plants

\begin{tabular}{|c|c|c|c|c|c|}
\hline \multirow[t]{2}{*}{ Plant name } & \multirow[t]{2}{*}{ Parts } & \multirow[t]{2}{*}{ Extracts } & \multicolumn{2}{|l|}{$\mathrm{EC}_{50}(\mu \mathrm{g} / \mathrm{ml})$} & \multirow{2}{*}{$\begin{array}{l}\text { Selectivity } \\
\text { index (SI) }\end{array}$} \\
\hline & & & P. falciparum K1 & MDBK cells & \\
\hline \multirow[t]{3}{*}{ Curcuma zedoaria } & \multirow[t]{3}{*}{ Rhizomes } & DCM & 2.38 & 37.61 & 15.92 \\
\hline & & $\mathrm{MeOH}$ & $>15.70$ & NT & ND \\
\hline & & $\mathrm{H}_{2} \mathrm{O}$ & $>15.70$ & NT & ND \\
\hline \multirow[t]{3}{*}{ Vernonia amygdalina } & \multirow[t]{3}{*}{ Leaves } & DCM & 3.36 & 157.69 & 47.00 \\
\hline & & $\mathrm{MeOH}$ & 1.09 & $>300$ & $>274.39$ \\
\hline & & $\mathrm{H}_{2} \mathrm{O}$ & 8.23 & $>600$ & $>72.95$ \\
\hline \multirow[t]{3}{*}{ Alpinia galanga } & \multirow[t]{3}{*}{ Rhizomes } & DCM & 1.64 & 3.92 & 2.40 \\
\hline & & $\mathrm{MeOH}$ & 8.06 & 87.95 & 10.92 \\
\hline & & $\mathrm{H}_{2} \mathrm{O}$ & 1.84 & $>50$ & $>27.16$ \\
\hline \multirow[t]{12}{*}{ Brucea javanica } & \multirow[t]{3}{*}{ Leaves } & DCM & 0.55 & 15.13 & 27.64 \\
\hline & & $\mathrm{MeOH}$ & 5.27 & 87.95 & 16.70 \\
\hline & & $\mathrm{H}_{2} \mathrm{O}$ & 1.29 & 1.90 & 1.48 \\
\hline & \multirow[t]{3}{*}{ Roots } & DCM & 0.47 & 6.54 & 14.05 \\
\hline & & $\mathrm{MeOH}$ & 0.58 & 6.95 & 12.06 \\
\hline & & $\mathrm{H}_{2} \mathrm{O}$ & 4.49 & 9.59 & 2.14 \\
\hline & \multirow[t]{3}{*}{ Green seeds } & DCM & $>15.70$ & NT & ND \\
\hline & & $\mathrm{MeOH}$ & 0.25 & NT & ND \\
\hline & & $\mathrm{H}_{2} \mathrm{O}$ & 1.47 & NT & ND \\
\hline & \multirow[t]{3}{*}{ Black seeds } & DCM & $>15.70$ & NT & ND \\
\hline & & $\mathrm{MeOH}$ & 1.96 & 7.70 & 3.92 \\
\hline & & $\mathrm{H}_{2} \mathrm{O}$ & 5.40 & 24.24 & 4.49 \\
\hline \multirow[t]{3}{*}{ Leea indica } & \multirow[t]{3}{*}{ Leaves } & DCM & $>15.70$ & NT & ND \\
\hline & & $\mathrm{MeOH}$ & $>15.70$ & NT & ND \\
\hline & & $\mathrm{H}_{2} \mathrm{O}$ & $>15.70$ & NT & ND \\
\hline \multirow[t]{3}{*}{ Cinnamomun iners } & \multirow[t]{3}{*}{ Leaves } & DCM & 1.95 & 199.15 & 102.58 \\
\hline & & $\mathrm{MeOH}$ & 0.63 & $>400$ & $>636.61$ \\
\hline & & $\mathrm{H}_{2} \mathrm{O}$ & 0.62 & $>100$ & $>161.29$ \\
\hline \multirow[t]{3}{*}{ Vitex negundo } & \multirow[t]{3}{*}{ Leaves } & DCM & 1.10 & 25.04 & 22.80 \\
\hline & & $\mathrm{MeOH}$ & 2.17 & $>50$ & $>23.10$ \\
\hline & & $\mathrm{H}_{2} \mathrm{O}$ & $>15.70$ & NT & ND \\
\hline \multirow[t]{3}{*}{ Terminalia catappa } & \multirow[t]{3}{*}{ Leaves } & DCM & 5.29 & $>50$ & $>9.45^{a}$ \\
\hline & & $\mathrm{MeOH}$ & 5.19 & $>50$ & $>9.63^{\mathrm{a}}$ \\
\hline & & $\mathrm{H}_{2} \mathrm{O}$ & 4.28 & 25.02 & 5.84 \\
\hline Morinda elliptica & Leaves & DCM & 9.08 & $>50$ & $>5.51^{\mathrm{a}}$ \\
\hline & & $\mathrm{MeOH}$ & 7.76 & $>50$ & $>6.45^{\mathrm{a}}$ \\
\hline & & $\mathrm{H}_{2} \mathrm{O}$ & 0.50 & 31.05 & 62.10 \\
\hline Annona muricata & Leaves & DCM & 0.61 & 40.48 & 66.47 \\
\hline & & $\mathrm{MeOH}$ & 0.26 & $>100$ & $>387.60$ \\
\hline & & $\mathrm{H}_{2} \mathrm{O}$ & 0.27 & $>200$ & $>756.14$ \\
\hline Curcuma mangga & Rhizomes & DCM & 6.59 & 36.66 & 4.09 \\
\hline & & $\mathrm{MeOH}$ & 1.81 & $>50$ & 15.44 \\
\hline & & $\mathrm{H}_{2} \mathrm{O}$ & 2.30 & 31.85 & 11.27 \\
\hline
\end{tabular}


Table 4 The antiplasmodial and cytotoxicity activities of $\mathrm{DCM}, \mathrm{MeOH}$ and $\mathrm{H}_{2} \mathrm{O}$ extracts of selected Malaysian medicinal plants (Continued)

\begin{tabular}{|c|c|c|c|c|c|}
\hline \multirow[t]{6}{*}{ Elephantopus scaber } & \multirow[t]{3}{*}{ Leaves } & DCM & 3.71 & 8.89 & 11.27 \\
\hline & & $\mathrm{MeOH}$ & 0.27 & 42.75 & 2.39 \\
\hline & & $\mathrm{H}_{2} \mathrm{O}$ & $>15.70$ & NT & ND \\
\hline & \multirow[t]{3}{*}{ Roots } & DCM & $>15.70$ & NT & ND \\
\hline & & $\mathrm{MeOH}$ & $>15.70$ & NT & ND \\
\hline & & $\mathrm{H}_{2} \mathrm{O}$ & $>15.70$ & NT & ND \\
\hline \multirow[t]{3}{*}{ Curcuma aeruginosa } & \multirow[t]{3}{*}{ Rhizomes } & DCM & 5.40 & $>50$ & $>9.26^{a}$ \\
\hline & & $\mathrm{MeOH}$ & 5.32 & $>50$ & $>9.39^{\mathrm{a}}$ \\
\hline & & $\mathrm{H}_{2} \mathrm{O}$ & 4.78 & $>50$ & $>10.46$ \\
\hline \multirow[t]{3}{*}{ Curcuma phaeocaulis } & \multirow[t]{3}{*}{ Rhizomes } & DCM & 5.00 & 11.04 & 2.21 \\
\hline & & $\mathrm{MeOH}$ & 9.24 & $>50$ & $>5.41^{\mathrm{a}}$ \\
\hline & & $\mathrm{H}_{2} \mathrm{O}$ & 10.45 & NT & ND \\
\hline
\end{tabular}

Data are presented as mean of at least two independent experiments performed in duplicate assays. $\mathrm{DCM}$, dichloromethane; $\mathrm{MeOH}$, methanol; $\mathrm{H}_{2} \mathrm{O}$, water extracts. No activity at the highest tested concentration denoted as $\mathrm{EC}_{50}>15.70 \mu \mathrm{g} / \mathrm{ml}$. No toxicity at the highest tested concentration denoted as $\mathrm{EC}_{50}>50.00$ 100, 200, 300, 400 and $600 \mu \mathrm{g} / \mathrm{ml}$. SI: $\mathrm{EC}_{50}$ MDBK cell lines $/ \mathrm{EC}_{50}$ Plasmodium. ${ }^{\mathrm{a}}$ The $\mathrm{SI}$ is not conclusive because the $\mathrm{EC}_{50}$ value is higher than $50 \mu \mathrm{g} / \mathrm{ml}$ which might resulted in higher $\mathrm{SI}$ value. NT, not tested, ND, not determined.

In vitro $P$. falciparum HRP2 and MTT assays were conducted for each plant extracts on CQ resistant $P$. falciparum and MDBK cell line, respectively. The EC ${ }_{50}$ value for each plants extracts were determined from the dose-response curves produced by using the HN-nonLin software (malaria.farch.net). The ratio of MDBK cell line $\mathrm{EC}_{50}$ and $P$. falciparum $\mathrm{EC}_{50}$ of each extract give the $\mathrm{SI}$ index or the level of toxic effects. Twenty three extracts from 11 plant species showed promising antiplasmodial activity $\left(\mathrm{EC}_{50} \leq 10 \mu \mathrm{g} / \mathrm{ml}\right)$ with no toxic effect $(\mathrm{SI} \geq 10)$.

against the MDBK cell lines (Table 4). In fact, the pharmacological efficacy of the extracts is considered selective and nontoxic when SI is $\geq 10$ [43]. Twenty three of antiplasmodial plant extracts (DCM, $\mathrm{MeOH}$ or $\mathrm{H}_{2} \mathrm{O}$ ) from 11 plant species showed a specific selectivity (SI $>10$ ) towards chloroquine resistant P. falciparum, K1 rather than MDBK cells with SI ranging from 10.46 to 756.14 (Table 4). The extract from B. javanica green seed was not tested for MTT assay and has been excluded from this experiment.

\section{Discussion}

The present study has identified the antiplasmodial activity in selected plant extracts by HRP2-based assay or HRP2 ELISA technique. There are other reports on antiplasmodial studies using different screening methods such as WHO schizont maturation test [44], isotopic assay [45], pLDH enzymatic assay [46,47], SYBR Green I assay [48-50] or fluocytometric assay [51]. Briefly, the HRP2based assay is a very sensitive and specific measures of $P$. falciparum growth by quantifying parasite specific biomolecule, HRP2. The suitability, reproducibility and sensitivity of HRP2-based assay in antimalarial drug screening is well documented since year 2002 [16,39,52-55]. The HRP2based assay is comparable with other techniques because the result produced by this assay has been previously shown to be closely parallel those obtained from the isotopic assay, traditional WHO schizont maturation tests [54] and SYBR green I assay [56].

Eleven plants (79\%) were identified to possess promising antimalarial properties in at least one of their extracts ( $\mathrm{DCM}, \mathrm{MeOH}$ or $\mathrm{H}_{2} \mathrm{O}$ ). These findings are based on their potent antiplasmodial activities $\left(\mathrm{EC}_{50} \leq\right.$ $10 \mu \mathrm{g} / \mathrm{ml}$ ) and high preferences in killing the malaria parasite rather than mammalian cell line (SI $\geq 10$ ) (Table 4). Most of the potential antiplasmodial activity were exhibited by DCM and $\mathrm{MeOH}$ extracts which may be related to the presence of alkaloids, terpenoids and flavonoids $[57,58]$. Theoretically, the purpose of using this extraction technique is to extract specific classes of phytochemical constituents from non-polar compounds to polar compounds [59]. The crude extract of DCM usually contains intermediate polarity of compounds such as alkaloids, steroids and terpenoids [59-61]. These classes of compounds especially alkaloids are well known as active constituents against antiplasmodial activity. In fact, one of the oldest and most known antimalarial drug, quinine belongs to this class of compounds. In addition, an example of common terpenoids is artemisinin, the most potent antimalarial to date [58]. Extraction with methanol will extract more polar compounds such as flavonoid glycosides, saponin, tannins and anthocyanins [59-61]. The antimalarial activity from these classes of compounds especially flavonoids have been described earlier [57]. Further extraction with water will extract high polarity of compounds such as phenolic acids, sugars and glycosides [59-61].

In another point of view, majority of these plants also possessed at least $1 \%$ of CQ antiplasmodial activity indicating the potential of these plants to be the source of antimalarial candidates. For example, the ethanolic extract of Artemisia annua Linn leaves (the source of artemisinin) 
Table 5 The summary of antiplasmodial level of extracts from different parts of 14 plant species

\begin{tabular}{|c|c|c|c|}
\hline Antiplasmodial level & Plant species & Parts & Extracts \\
\hline \multirow[t]{7}{*}{ Good $\mathrm{EC}_{50}=0.1-1.0 \mathrm{\mu g} / \mathrm{ml}$} & A. muricata & Leaves & $\mathrm{DCM}, \mathrm{MeOH}, \mathrm{H}_{2} \mathrm{O}$ \\
\hline & B. javanica & Green seeds & $\mathrm{MeOH}$ \\
\hline & & Roots & $\mathrm{DCM}, \mathrm{MeOH}$ \\
\hline & & Leaves & DCM \\
\hline & E. scaber & Leaves & $\mathrm{MeOH}$ \\
\hline & M. elliptica & Leaves & $\mathrm{H}_{2} \mathrm{O}$ \\
\hline & C. iners & Leaves & $\mathrm{H}_{2} \mathrm{O}, \mathrm{MeOH}$ \\
\hline \multirow[t]{15}{*}{ Good to moderate $\mathrm{EC}_{50}=1.1-10 \mu \mathrm{g} / \mathrm{ml}$} & V. amygdalina & Leaves & $\mathrm{DCM}, \mathrm{MeOH}$ and $\mathrm{H}_{2} \mathrm{O}$ \\
\hline & A. galanga & Rhizomes & $\mathrm{DCM}, \mathrm{MeOH}$ and $\mathrm{H}_{2} \mathrm{O}$ \\
\hline & T. catappa & Leaves & $\mathrm{DCM}, \mathrm{MeOH}$ and $\mathrm{H}_{2} \mathrm{O}$ \\
\hline & C. mangga & Rhizomes & $\mathrm{DCM}, \mathrm{MeOH}$ and $\mathrm{H}_{2} \mathrm{O}$ \\
\hline & C. aeruginosa & Rhizomes & $\mathrm{DCM}, \mathrm{MeOH}$ and $\mathrm{H}_{2} \mathrm{O}$ \\
\hline & C. zedoaria & Rhizomes & DCM \\
\hline & E. scaber & Leaves & DCM \\
\hline & B. javanica & Leaves & $\mathrm{MeOH}$ and $\mathrm{H}_{2} \mathrm{O}$ \\
\hline & & Roots & $\mathrm{H}_{2} \mathrm{O}$ \\
\hline & & Green seeds & $\mathrm{H}_{2} \mathrm{O}$ \\
\hline & & Black seeds & $\mathrm{MeOH}$ and $\mathrm{H}_{2} \mathrm{O}$ \\
\hline & C. iners & Leaves & DCM \\
\hline & V. neguno & Leaves & $\mathrm{DCM}$ and $\mathrm{MeOH}$ \\
\hline & M. elliptica & Leaves & $\mathrm{DCM}$ and $\mathrm{MeOH}$ \\
\hline & C. phaeocaulis & Rhizomes & $\mathrm{DCM}$ and $\mathrm{MeOH}$ \\
\hline \multirow[t]{8}{*}{ Weak $\mathrm{EC}_{50}=11-25 \mu \mathrm{g} / \mathrm{ml}$} & C. phaeocaulis & Rhizomes & $\mathrm{H}_{2} \mathrm{O}$ \\
\hline & B. javanica & Green seeds & DCM \\
\hline & & Black seeds & DCM \\
\hline & L. indica & Leaves & $\mathrm{DCM}, \mathrm{MeOH}$ and $\mathrm{H}_{2} \mathrm{O}$ \\
\hline & C. zedoaria & Rhizomes & $\mathrm{MeOH}$ and $\mathrm{H}_{2} \mathrm{O}$ \\
\hline & V. negundo & Leaves & $\mathrm{H}_{2} \mathrm{O}$ \\
\hline & E. scaber & Leaves & $\mathrm{H}_{2} \mathrm{O}$ \\
\hline & & Roots & $\mathrm{DCM}, \mathrm{MeOH}$ and $\mathrm{H}_{2} \mathrm{O}$ \\
\hline
\end{tabular}

The level of efficacy of extracts were ranked according $\mathrm{EC}_{50}$ values which based on the threshold for in vitro antiplasmodial activity proposed by Rasoanaivo et al. [41]. Forty one extracts from 13 plant species were categorized to have good and good to moderate antiplasmodial level.

inhibited the growth of CQ resistant (K1) and CQ sensitive (3D7) strains of $P$. falciparum with $\mathrm{IC}_{50}$ of $10.4 \mu \mathrm{g} / \mathrm{ml}$ and $21.8 \mu \mathrm{g} / \mathrm{ml}$, respectively [49]. So, even the plant like A. annua with weak antiplasmodial activity (only $0.007 \%$ and $0.004 \%$ of artesunate activity against $P$. falciparum $\mathrm{K} 1$ and $3 \mathrm{D} 7$, respectively) contains the most potent antimalarial compound to date. This phenomenon may also apply to the plants extracted in this study.

In this study, A. galanga (rhizome), C. iners (leaf), $C$. zedoaria (rhizome), E. scaber (leaf), C. mangga (rhizome) and M. elliptica (leaf) were for the first time reported for their good level of antiplasmodial activities in vitro. Other potent antiplasmodial plants such as $C$. aeruginosa (rhizome) [62], $V$. negundo (leaf) [46], $B$. javanica (leaf and root) [45,51,62], A. muricata (leaf) [63] and $V$. amygdalina (leaf) [44,64-68] have been widely studied and were further discussed in this section.

\section{A. galanga}

The A. galanga has been identified as one of the plants traditionally used in some part of Peninsular Malaysia [11]. The in vitro antiplasmodial data of A. galanga rhizome extracts $\left(\mathrm{EC}_{50}<10 \mu \mathrm{g} / \mathrm{ml}\right)$ reported by present study is complementing the in vivo study conducted by Al-Adhroey et al. [11]. The $\mathrm{MeOH}$ extract of the rhizome exhibited a significant suppressive, curative and prophylactic activities on $P$. berghei infected mice. The antimalarial properties of $\mathrm{MeOH}$ extract of A. galanga 
rhizome could be governed by its active constituents such as flavonoids and terpenoids [18]. In addition, both terpenoids and flavonoids related compounds have been previously shown to exhibit antiplasmodial activities against several P. falciparum strains [57].

\section{E. scaber}

In this study, the good level of antiplasmodial activity showed by the $\mathrm{MeOH}$ extract of $E$. scaber leaf $\left(\mathrm{EC}_{50}=\right.$ $0.27 \mu \mathrm{g} / \mathrm{ml}$ ) was contradictory to the study reported by Kantamreddi and Wright [46]. According to Kantamreddi and Wright [46], the $\mathrm{MeOH}$ extract of the leaves of this plant was considered inactive $\left(\mathrm{IC}_{50}=133.8 \mu \mathrm{g} / \mathrm{ml}\right)$ against CQ resistant $P$. falciparum (K1) [46]. The possible reason for the contradictory results could be due to the differences in the duration of incubation in antiplasmodial assay. The incubation period for the present study is longer (72 hours) than the Kantamreddi and Wright [46] study (48 hours). The 72 hours incubation period allows the activity of the substance to affect the merozoite reinvasion process whereas the 48 hours incubation period will only affect the intraerythrocytic growth of the malaria parasites. In this case, the $\mathrm{MeOH}$ extract of this plant might not so effective against the ring to schizont intraerythrocytic stages of P. falciparum. Other species of Elephantopus such as E. mollis have been shown to possess potential antiplasmodial activity $\left(\mathrm{IC}_{50}=2.2 \mu \mathrm{g} / \mathrm{ml}\right)$ against $\mathrm{CQ}$ resistant P. falciparum (K1) [69].

\section{M. elliptica}

To our knowledge, this plant had not yet been investigated for the in vitro antiplasmodial activity. However other species of Morinda, M. morindoides has been shown to exhibit a pronounced antiplasmodial activity [64].

\section{C. iners}

The only antiplasmodial study on $C$. iners was previously reported for its roots extract. However, the $\mathrm{MeOH}$ extract of $C$. iners roots exhibited weak antiplasmodial activity $\left(\mathrm{IC}_{50}=12.7 \mu \mathrm{g} / \mathrm{ml}\right)$ against $\mathrm{CQ}$ resistant $P$. falciparum (FCR-3) [21]. In contrast, the leaves extract $(\mathrm{MeOH})$ of this plant which was prepared by present study exhibited a good antiplasmodial activity $\left(\mathrm{EC}_{50}=\right.$ $0.63 \mu \mathrm{g} / \mathrm{ml}$ ) (Table 4). In addition, other Cinnamomun species, C. griffithii has been reported to elicit a promising antiplasmodial activity $\left(\mathrm{IC}_{50}<10 \mu \mathrm{g} / \mathrm{ml}\right)$ against both CQ sensitive and resistant P. falciparum strains [70]. To our knowledge, there is no compound related to this plant reported for antiplasmodial activity.

\section{Curcuma sp.}

The member of the Curcuma plant species such as $C$. zedoaria, C. mangga, C. aeruginosa and others were well studied for their antiparasiticidal properties [71]. The
$\mathrm{H}_{2} \mathrm{O}$ extracts of $C$. xanthorriza and $C$. aeruginosa were previously found to be effective in inhibiting P. falciparum in vitro (40\% and $90 \%$ inhibition, respectively). However the concentration of the extracts used $(1 \mathrm{mg} / \mathrm{ml})$ was too high [62]. Moreover, the major antiplasmodial compounds like curcumin and its derivatives such as demethoxycurcumin and bis-demethoxycurcumin isolated from $C$. longa exhibited high $\mathrm{IC}_{50}$ value $\left(\mathrm{IC}_{50}>5 \mu \mathrm{M}\right)$ [72]. In contrast, by different technique of plant extraction, the present study showed a promising antiplasmodial activity $\left(\mathrm{EC}_{50}<10 \mu \mathrm{g} / \mathrm{ml}\right)$ of C. zedoaria (DCM extract), C. aeruginosa ( $\mathrm{H}_{2} \mathrm{O}$ extract) and $C$. mangga ( $\mathrm{MeOH}$ and $\mathrm{H}_{2} \mathrm{O}$ extracts) with negligible toxic effect on normal cell line $(\mathrm{SI}>10)$ (Table 4 and 5). Although the antiplasmodial activity of Curcuma $s p$ isolated compound such as curcumin is considered weak, it was found to be very effective in antimalarial drug combination study [15,73-75].

\section{V. amygdalina}

The $V$. amygdalina plant is also found in African countries and is widely used traditionally in treating fever, malaria, measles, diabetes, worms, hypertension and others [76,77]. The ethanol, petroleum ether, methylene chloride and $\mathrm{MeOH}$ extracts of $V$. amygdalina leaf have been previously reported to elicit $\mathrm{IC}_{50}$ values of less than $10 \mu \mathrm{g} / \mathrm{ml}$ against $P$. falciparum [64,65]. Both ethanolic and $\mathrm{H}_{2} \mathrm{O}$ extracts of $V$. amygdalina leaf has also been shown to inhibit schizont maturation of fresh P. falciparum isolates from patients with negligible toxicity in rats [44]. In addition, the in vivo antimalarial activity of this plant has also been reported [66-68]. In in vivo drug combination experiment, the decoction of $V$. amygdalina leaves has the ability to enhance the CQ activity in $P$. berghei infected mice [68]. Furthermore, the infusion of $V$. amygdalina leaves has been clinically tested against the uncomplicated malaria where the parasite clearance has been documented [78]. So, it is not surprising to see a promising antiplasmodial activity of $V$. amygdalina leaf extracts (DCM, MeOH and $\mathrm{H}_{2} \mathrm{O}$ extracts) as showed by the present study $\left(\mathrm{EC}_{50}<10 \mu \mathrm{g} / \mathrm{ml}\right)$ (Table 4$)$. The antimalarial property of this plant could be due to the presence of its active constituents, sesquiterpene lactones such as vernolepin, vernolin, vernolide, vernodalin and hydroxyvernodalin [79].

\section{B. javanica}

The B. javanica grows in Asia Pacific region including China, Indonesia, Malaysia and Thailand [45]. Different parts of this plant such as fruit, roots, seeds, stems and bark are traditionally used in treating variety of diseases including babesiosis, malaria and cancer. The $\mathrm{H}_{2} \mathrm{O}$ extract of $B$. javanica leaves, fruits and bark have been shown to possess a strong antiplasmodial activity against 
P. falciparum [62]. In the present study, the DCM and $\mathrm{MeOH}$ extracts of $B$. javanica leaves and roots showed good $\left(\mathrm{EC}_{50}<1 \mu \mathrm{g} / \mathrm{ml}\right)$ to good to moderate $\left(\mathrm{EC}_{50}=1.1\right.$ to $10 \mu \mathrm{g} / \mathrm{ml}$ ) level of antiplasmodial activities against CQ resistant $P$. falciparum, K1 (Table 4 ). By similar extraction procedure, the DCM, MeOH and $\mathrm{H}_{2} \mathrm{O}$ extracts $B$. javanica roots have also been previously reported to possess a good to moderate level antiplasmodial activity against another CQ resistant $P$. falciparum strain, W2 with $\mathrm{IC}_{50}$ ranging from 1.0 to $2.0 \mu \mathrm{g} / \mathrm{ml}$ [51]. The antiplasmodial activity showed by this plant might be governed by its active constituents such as quassinoids, alkaloids (bruceacanthinoside) and triterpenoids (Bruceajavanin A and dihydrobruceajavanin A) [80,81]. Other plant from the same family (Simaroubaceae) like E. longifolia also exhibited an antiplasmodial activity ruled by its quassinoids and alkaloids contents [25,82]. In addition, the present study has identified the antiplasmodial activity from seeds of this plant $(\mathrm{MeOH}$ and $\mathrm{H}_{2} \mathrm{O}$ extracts). However, the DCM extract of the seeds seem to have weak or no antiplasmodial activity $\left(\mathrm{EC}_{50}>\right.$ $15.7 \mu \mathrm{g} / \mathrm{ml}$ ) (Table 4). In another study with different extraction procedure, the extracts of $B$. javanica fruits (ethanol, $\mathrm{MeOH}$-ethanol, aqueous- $\mathrm{MeOH}$ residue, ethyl acetate and ethyl alcohol extracts) have been shown to have a promising antiplasmodial activity against $P$. falciparum $\mathrm{K} 1$ strain $\left(\mathrm{IC}_{50}<10 \mu \mathrm{g} / \mathrm{ml}\right)$. In contrast, the $\mathrm{H}_{2} \mathrm{O}$ extract of the fruits showed weak antiplasmodial activity $\left(\mathrm{IC}_{50}>10 \mu \mathrm{g} / \mathrm{ml}\right)$ [45].

\section{V. negundo}

The $V$. negundo has been traditionally used in India as antiseptic, anti-inflammatory, antipyretic, treating enlargement of spleen and others [83]. The present study has highlighted the potential antiplasmodial activity of $\operatorname{DCM}\left(\mathrm{EC}_{50}=1.1 \mu \mathrm{g} / \mathrm{ml}\right)$ and $\mathrm{MeOH}\left(\mathrm{EC}_{50}=2.17 \mu \mathrm{g} / \mathrm{ml}\right)$ extracts of $V$. negundo leaves against the CQ resistant $P$. falciparum. The $\mathrm{MeOH}$ extracts of $V$. negundo leaf has been previously shown to exhibit a promising antiplasmodial activity against $\mathrm{CQ}$ sensitive $\left(\mathrm{IC}_{50}=9.5 \mu \mathrm{g} / \mathrm{ml}\right) P$. falciparum but not to CQ resistant $P$. falciparum strain $\left(\mathrm{IC}_{50}=19.8 \mu \mathrm{g} / \mathrm{ml}\right)$. In similar study, the $\mathrm{MeOH}$ extract of the flower of this plant also exhibited a promising antiplasmodial activity with $\mathrm{IC}_{50}$ value of against $\mathrm{CQ}$ sensitive $\left(\mathrm{IC}_{50}=2.8 \mu \mathrm{g} / \mathrm{ml}\right)$ but not to $\mathrm{CQ}$ resistant $P$. falciparum $\left(\mathrm{IC}_{50}=17.8 \mu \mathrm{g} / \mathrm{ml}\right)[46]$.

\section{A. muricata}

As reported by Osorio et al. [63], the hexane, ethyl acetate and $\mathrm{MeOH}$ extract of $A$. muricata leaf exhibited good to moderate level of antiplasmodial activities against CQ sensitive $P$. falciparum strain F32 ( $\mathrm{IC}_{50}$ ranging from 7.2 to $9.2 \mu \mathrm{g} / \mathrm{ml}$ ) but not to CQ resistant strain W2 ( $\mathrm{IC}_{50}$ ranging from 10.4 to $\left.38.6 \mu \mathrm{g} / \mathrm{ml}\right)$ [63].
However, the most potent ethyl acetate extracts of this plant is considered toxic to U-937 cells (human monocytes) ( $\mathrm{SI}=1.1$ and 0.2 for F32 and W2 P. falciparum strains, respectively). On the other hand, with different extraction approach, the present study not only showing the promising antiplasmodial activity of $A$. muricata leaves extracts (DCM, $\mathrm{MeOH}$ and $\mathrm{H}_{2} \mathrm{O}$ extracts) $\left(\mathrm{EC}_{50}<10 \mu \mathrm{g} / \mathrm{ml}\right)$, but also the non-toxic activity of the extract to MDBK cells $(\mathrm{SI}=66-756)$ (Table 4 and 5).

\section{Conclusions}

Twenty three extracts derived from C. zedoaria (rhizome), C. aeruginosa (rhizome), A. galanga (rhizome), $V$. negundo (leaf), M. elliptica (leaf), C. mangga (rhizome), E. scaber (leaf), B. javanica (leaf and root), $A$. muricata (leaf), $C$. iners (leaf) and $V$. amygdalina (leaf) showed the best antiplasmodial activities against the blood stage chloroquine resistant $P$. falciparum with no toxic effects on MDBK cells $(\mathrm{SI} \geq 10)$. The present study has also scientifically supported the efficacy of $B$. javanica and $A$. galanga which are used traditionally to treat malaria in Peninsular Malaysia. Although these plant extracts were able to kill the $P$. falciparum in vitro, further in vivo evaluation is needed to demonstrate their efficacy in treating mammalian malaria model. Furthermore, the bioassay guided fractionation is a way forward for determination of bioactive compounds which will lead to the formulation of new antimalarial drugs or standardized antimalarial extracts.

\section{Competing interests}

The authors declare that they have no competing interests.

\section{Authors' contributions}

MRMAR involves manuscript preparation, data interpretation and analysis. AA and RA carried out the plant extraction and cytotoxicity test. NFAJ involves in antiplasmodial screening of plant extracts and data analysis. MIW involves in consultation of plant extraction procedure. SHSZ involves in the preparation of plant specimens for species identification. NRA contributes in overall project design and concept. $\mathrm{ZI}$ involves in revising and giving the final approval of the version to be published. All authors read and approved the final manuscript.

\section{Authors' information}

All the authors are researchers from Bioassay and Phytochemistry Units of Herbal Medicine Research Centre, Institute for Medical Research, Kuala Lumpur, Malaysia.

\section{Acknowledgements}

The authors would like to thank the Director General of Health Malaysia for the permission to publish this paper. We thank the Director for the Institute for Medical Research (IMR), Kuala Lumpur for her critical review and support in publishing this paper. The authors also wish to thank the staff of Phytochemistry and Information Units, Herbal Medicine Research Centre, IMR, Kuala Lumpur who has contributed in this study. This study, NMRR-13-424-16108 was supported by the National Institute of Health, Ministry of Health Malaysia.

Received: 3 March 2014 Accepted: 11 December 2014 Published: 15 December 2014

\section{References}

1. Abdullah NR, Norahmad NA, Jelip J, Sulaiman LH, Mohd Sidek H, Ismail Z, Noedl $\mathrm{H}$ : High prevalence of mutation in the Plasmodium falciparum $\mathrm{dhfr}$ 
and dhps genes in field isolates from Sabah, Northern Borneo. Malar J 2013, 12(1):198.

2. Norahmad NA, Abdullah NR, Yaccob N, Jelip J, Dony JF, Ruslan KF, Sulaiman LH, Sidek HM, Noedl H, Ismail Z: High prevalence of pfcrt K76t mutants among Plasmodium falciparum isolates from Sabah, Malaysia. Southeast Asian J Trop Med Public Health 2011, 42(6):1322-1326.

3. Lokman Hakim S, Sharifah Roohi SW, Zurkurnai Y, Noor Rain A, Mansor SM, Palmer K, Navaratnam V, Mak JW: Plasmodium falciparum: increased proportion of severe resistance (RII and RIII) to chloroquine and high rate of resistance to sulfadoxine-pyrimethamine in Peninsular Malaysia after two decades. Trans R Soc Trop Med Hyg 1996, 90(3):294-297.

4. Phyo AP, Nkhoma S, Stepniewska K, Ashley EA, Nair S, McGready R, ler Moo C, Al-Saai S, Dondorp AM, Lwin KM, Singhasivanon P, Day NP, White NJ, Anderson TJ, Nosten F: Emergence of artemisinin-resistant malaria on the western border of Thailand: a longitudinal study. Lancet 2012, 379(9830):1960-1966.

5. Baliraine FN, Rosenthal PJ: Prolonged selection of pfmdr1 polymorphisms after treatment of falciparum malaria with artemether-lumefantrine in Uganda. J Infect Dis 2011, 204(7):1120-1124.

6. Farnert A, Ursing J, Tolfvenstam T, Rono J, Karlsson L, Sparrelid E, Lindegardh N: Artemether-lumefantrine treatment failure despite adequate lumefantrine day 7 concentration in a traveller with Plasmodium falciparum malaria after returning from Tanzania. Malar J 2012, 11:176.

7. Wongsrichanalai $\mathrm{C}$, Sibley $\mathrm{CH}$ : Fighting drug-resistant Plasmodium falciparum: the challenge of artemisinin resistance. Clin Microbiol Infect 2013, 19(10):908-916

8. Wongsrichanalai C: Artemisinin resistance or artemisinin-based combination therapy resistance? Lancet Infect Dis 2013, 13(2):114-115.

9. Na-Bangchang K, Muhamad P, Ruaengweerayut R, Chaijaroenkul W, Karbwang J: Identification of resistance of Plasmodium falciparum to artesunate-mefloquine combination in an area along the Thai-Myanmar border: integration of clinico-parasitological response, systemic drug exposure, and in vitro parasite sensitivity. Malar J 2013, 12:263

10. Willcox M, Burford G, Bodeker G: An overview of ethnobotanical studies on plants used for the treatment of malaria. In Traditional Medicinal Plant and Malaria. Edited by Willcox M, Bodeker G, Rasoanaivo P. Florida: CRC Press; 2004:187-197.

11. Al-Adhroey AH, Nor ZM, Al-Mekhlafi HM, Mahmud R: Ethnobotanical study on some Malaysian anti-malarial plants: a community based survey. J Ethnopharmacol 2010, 132(1):362-364.

12. Ong HC, Chua S, Milow P: Ethno-medicinal plants used by the Temuan villagers in Kampung Jeram Kedah, Negeri Sembilan, Malaysia. Ethno Med 2011, 5(2):95-100.

13. Ong HC, Nordiana M: Malay ethno-medico botany in Machang, Kelantan, Malaysia. Fitoterapia 1999, 70:502-513.

14. Elfawal MA, Towler MJ, Reich NG, Golenbock D, Weathers PJ, Rich SM: Dried whole plant Artemisia annua as an antimalarial therapy. PLoS One 2012, 7(12):e52746.

15. Rasoanaivo P, Wright CW, Willcox ML, Gilbert B: Whole plant extracts versus single compounds for the treatment of malaria: synergy and positive interactions. Malar J 2011, Suppl 1:\$4.

16. Noedl H, Wernsdorfer WH, Miller RS, Wongsrichanalai C: Histidine-rich protein II: a novel approach to malaria drug sensitivity testing. Antimicrob Agents Chemother 2002, 46(6):1658-1664.

17. Noor Rain A, Khozirah S, Mohd Ridzuan MA, Ong BK, Rohaya C, Rosilawati M, Hamdino I, Badrul A, Zakiah I: Antiplasmodial properties of some Malaysian medicinal plants. Trop Biomed 2007, 24(1):29-35.

18. Al-Adhroey AH, Nor ZM, Al-Mekhlafi HM, Mahmud R: Median lethal dose, antimalarial activity, phytochemical screening and radical scavenging of methanolic Languas galanga rhizome extract. Molecules 2010, 15(11):8366-8376.

19. Wong SK, Lim YY, Abdullah NR, Nordin FJ: Assessment of antiproliferative and antiplasmodial activities of five selected Apocynaceae species. BMC Complement Altern Med 2011, 11:3.

20. Basir R, Chan KL, Yam MF, Othman F, Abdullah WO, Mohd Moklas MA, Abdul Rahim AS, Ismail IS, Hidayat MT, Mat Taib CN, Mahmud R: Antimalarial activity of selected Malaysian medicinal plants. Phytopharmacology 2012, 3(1):82-92.

21. Wan Omar A, Ngah ZU, Zaridah MZ, Noor Rain A: In vitro and in vivo antiplasmodial properties of some Malaysian plants used in traditional medicine. Infect Dis J Pakistan 2007, 16(4):97-101.
22. Siti Najila MJ, Noor Rain A, Mohamad Kamel AG, Syed Zahir SI, Khozirah S, Lokman Hakim S, Zakiah I, Azizol AK: The screening of extracts from Goniothalamus scortechinii, Aralidium pinnatifidum and Andrographis paniculata for anti-malarial activity using the lactate dehydrogenase assay. J Ethnopharmacol 2002, 82(2-3):239-242.

23. Al-Adhroey AH, Nor ZM, Al-Mekhlafi HM, Amran AA, Mahmud R: Evaluation of the use of Cocos nucifera as antimalarial remedy in Malaysian folk medicine. J Ethnopharmacol 2011, 134(3):988-991.

24. Nasrullah AA, Zahari A, Mohamad J, Awang K: Antiplasmodial alkaloids from the bark of Cryptocarya nigra (Lauraceae). Molecules 2013, 18(7):8009-8017.

25. Chan KL, Choo CY, Abdullah NR, Ismail Z: Antiplasmodial studies of Eurycoma longifolia Jack using the lactate dehydrogenase assay of Plasmodium falciparum. J Ethnopharmacol 2004, 92(2-3):223-227.

26. Ang HH, Chan $\mathrm{KL}$, Mak JW: In vitro antimalarial activity of quassinoids from Eurycoma longifolia against Malaysian chloroquine-resistant Plasmodium falciparum isolates. Planta Med 1995, 61(2):177-178.

27. Chan KL, Choo CY, Abdullah NR: Semisynthetic 15-O-acyl- and 1,15-di-Oacyleurycomanones from Eurycoma longifolia as potential antimalarials. Planta Med 2005, 71(10):967-969.

28. Vejanan V, Latip J, Chin LP, Embi N, Sidek HM: In vitro and in vivo antiplasmodial activities of Gynura procumbens. Sains Malaysiana 2012, 41(12):1535-1542.

29. Yapp DT, Yap SY: Lansium domesticum: skin and leaf extracts of this fruit tree interrupt the lifecycle of Plasmodium falciparum, and are active towards a chloroquine-resistant strain of the parasite (T9) in vitro. J Ethnopharmacol 2003, 85(1):145-150.

30. Faridahanim MJ, Abdul Hamid AH, Khalijah A, Nor Hadiani I, Noor Rain A: The screening of the extract from Leuconotis eugenifolius for antimalarial activity using the lactate dehydrogenase assay. In Malaysian Medicinal Plants: Chemistry and Biological Activity. 1st edition. Edited by Ahmad F, Assim Z, Din L, Said IM. Sarawak, Malaysia: UNIMAS and Malaysian Natural Products Society; 2006:23-26

31. Zakaria I, Ahmat N, Jaafar FM, Widyawaruyanti A: Flavonoids with antiplasmodial and cytotoxic activities of Macaranga triloba. Fitoterapia 2012, 83(5):968-972.

32. Awang K, Mukhtar MR, Hadi AH, Litaudon M, Latip J, Abdullah NR: New alkaloids from Phoebe grandis (Nees) Merr. Nat Prod Res 2006, 20(6):567-572.

33. Al-Adhroey AH, Nor ZM, Al-Mekhlafi HM, Amran AA, Mahmud R: Antimalarial activity of methanolic leaf extract of Piper betle L. Molecules 2011, 16(1):107-118.

34. Najib Nik ARN, Furuta T, Kojima S, Takane K, Ali Mohd M: Antimalarial activity of extracts of Malaysian medicinal plants. J Ethnopharmacol 1999, 64(3):249-254.

35. Osman CP, Ismail NH, Ahmad R, Ahmat N, Awang K, Jaafar FM: Anthraquinones with antiplasmodial activity from the roots of Rennellia elliptica Korth. (Rubiaceae). Molecules 2010, 15(10):7218-7226.

36. Burkill $I \mathrm{H}$ : A Dictionary of the Economic Products of the Malay Peninsula, Volume I and II. Ministry of Agriculture Malaysia: Kuala Lumpur, Malaysia; 1966.

37. Trager W, Jensen JB: Cultivation of erythrocytic stages. Bull World Health Organ 1977, 55(2-3):363-365.

38. Lambros C, Vanderberg JP: Synchronization of Plasmodium falciparum erythrocytic stages in culture. J Parasitol 1979, 65(3):418-420.

39. Noedl H, Bronnert J, Yingyuen K, Attlmayr B, Kollaritsch H, Fukuda M: Simple histidine-rich protein 2 double-site sandwich enzyme-linked immunosorbent assay for use in malaria drug sensitivity testing. Antimicrob Agents Chemother 2005, 49(8):3575-3577.

40. Mosmann T: Rapid colorimetric assay for cellular growth and survival: application to proliferation and cytotoxicity assays. J Immunol Methods 1983, 65(1-2):55-63.

41. Rasoanaivo P, Ramanitrahasimbola D, Rafatro H, Rakotondramanana D, Robijaona B, Rakotozafy A, Ratsimamanga-Urverg S, Labaied M, Grellier P, Allorge L, Mambu L, Frappier F: Screening extracts of Madagascan plants in search of antiplasmodial compounds. Phytother Res 2004, 18(9):742-747.

42. Sidhu AB, Verdier-Pinard D, Fidock DA: Chloroquine resistance in Plasmodium falciparum malaria parasites conferred by pfcrt mutations. Science 2002 , 298(5591):210-213.

43. Weniger B, Robledo S, Arango GJ, Deharo E, Aragon R, Munoz V, Callapa J, Lobstein A, Anton R: Antiprotozoal activities of Colombian plants. J Ethnopharmacol 2001, 78(2-3):193-200. 
44. Sha'a KK, Oguche S, Watila IM, Ikpa TF: In vitro antimalarial activity of the extracts of Vernonia amygdalina commonly used in traditional medicine in Nigeria. Sci World J 2011, 6(2):5-9.

45. Sriwilaijaroen $N$, Kondo $S$, Nanthasri $P$, Auparakkitanon $S$, Suzuki $Y$, Wilairat $P$. Antiplasmodial effects of Brucea javanica (L.) Merr. and Eurycoma longifolia Jack extracts and their cobination with chloroquine and quinine on Plasmodium falciparum in culture. Trop Med Health 2010, 38(2):61-68.

46. Kantamreddi VS, Wright CW: Screening Indian plant species for antiplasmodial properties-ethnopharmacological compared with random selection. Phytother Res 2012, 26(12):1793-1799.

47. Ondo JP, Lekana-Douki JB, Bongui JB, Zang Edou ES, Zatra R, Toure-Ndouo FS, Elomri A, Lebibi J, Seguin E: In vitro antiplasmodial activity and cytotoxicity of extracts and fractions of Vitex madiensis, medicinal plant of Gabon. Trop Med Int Health 2012, 17(3):316-321.

48. Bagavan A, Rahuman AA, Kaushik NK, Sahal D: In vitro antimalarial activity of medicinal plant extracts against Plasmodium falciparum. Parasitol Res 2011, 108(1):15-22

49. Thiengsusuk A, Chaijaroenkul W, Na-Bangchang K: Antimalarial activities of medicinal plants and herbal formulations used in Thai traditional medicine. Parasitol Res 2013, 112(4):1475-1481.

50. Kamaraj C, Kaushik NK, Rahuman AA, Mohanakrishnan D, Bagavan A, Elango G, Zahir AA, Santhoshkumar T, Marimuthu S, Jayaseelan C, Kirthi AV, Rajakumar G, Velayutham K, Sahal D: Antimalarial activities of medicinal plants traditionally used in the villages of Dharmapuri regions of South India. J Ethnopharmacol 2012, 141(3):796-802.

51. Hout S, Chea A, Bun SS, Elias R, Gasquet M, Timon-David P, Balansard G, Azas N: Screening of selected indigenous plants of Cambodia for antiplasmodial activity. J Ethnopharmacol 2006, 107(1):12-18.

52. Noedl H, Yingyuen $K$, Laoboonchai A, Fukuda M, Sirichaisinthop J, Miller RS Sensitivity and specificity of an antigen detection ELISA for malaria diagnosis. Am J Trop Med Hyg 2006, 75(6):1205-1208.

53. Noedl H, Attlmayr B, Wernsdorfer WH, Kollaritsch H, Miller RS: A histidinerich protein 2-based malaria drug sensitivity assay for field use. Am J Trop Med Hyg 2004, 71(6):711-714.

54. Noedl H, Wernsdorfer WH, Kollaritsch H, Looareesuwan S, Miller RS, Wongsrichanalai C: Malaria drug-susceptibility testing. HRP2-based assays: current data, future perspectives. Wien Klin Wochenschr 2003, 115(Suppl 3):23-27.

55. Noedl H, Wongsrichanalai C, Miller RS, Myint KS, Looareesuwan S, Sukthana Y, Wongchotigul V, Kollaritsch $H$, Wiedermann G, Wernsdorfer WH: Plasmodium falciparum: effect of anti-malarial drugs on the production and secretion characteristics of histidine-rich protein II. Exp Parasitol 2002 102(3-4):157-163.

56. Bacon DJ, Latour C, Lucas C, Colina O, Ringwald P, Picot S: Comparison of a SYBR green I-based assay with a histidine-rich protein II enzyme-linked immunosorbent assay for in vitro antimalarial drug efficacy testing and application to clinical isolates. Antimicrob Agents Chemother 2007, 51(4):1172-1178

57. Batista R, Silva Ade J Jr, de Oliveira AB: Plant-derived antimalarial agents: new leads and efficient phytomedicines. Part II. Non-alkaloidal natural products. Molecules 2009, 14(8):3037-3072.

58. Oliveira AB, Dolabela MF, Braga FC, Jacome RL, Varotti FP, Povoa MM: Plantderived antimalarial agents: new leads and efficient phythomedicines. Part I. Alkaloids. An Acad Bras Cienc 2009, 81(4):715-740.

59. Houghton PJ, Raman A: Laboratory Handbook for the Fractionation of Natural Extracts. 1st edition. London: Chapman \& Hall; 1998.

60. Tiwari P, Kumar B, Kaur M, Kaur G, Kaur K: Phytochemical screening and extraction: A review. Internationale Pharmaceutica Sciencia 2011, 1(1):98-106.

61. Cowan MM: Plant products as antimicrobial agents. Clin Microbiol Rev 1999, 12(4):564-582.

62. Murnigsih T, Subeki, Matsuura H, Takahashi K, Yamasaki M, Yamato O, Maede Y, Katakura K, Suzuki M, Kobayashi S, Chairul, Yoshihara T: Evaluation of the inhibitory activities of the extracts of Indonesian traditional medicinal plants against Plasmodium falciparum and Babesia gibsoni. J Vet Med Sci 2005, 67(8):829-831.

63. Osorio E, Arango GJ, Jimenez N, Alzate F, Ruiz G, Gutierrez D, Paco MA Gimenez A, Robledo S: Antiprotozoal and cytotoxic activities in vitro of Colombian Annonaceae. J Ethnopharmacol 2007, 111(3):630-635.

64. Tona L, Cimanga RK, Mesia K, Musuamba CT, De Bruyne T, Apers S, Hernans N, Van Miert S, Pieters L, Totte J, Vlietinck AJ: In vitro antiplasmodial activity of extracts and fractions from seven medicinal plants used in the Democratic Republic of Congo. J Ethnopharmacol 2004, 93(1):27-32.

65. Zofou D, Tene M, Ngemenya MN, Tane P, Titanji VP: In vitro antiplasmodial activity and cytotoxicity of extracts of selected medicinal plants used by traditional healers of Western cameroon. Malar Res Treat 2011, 2011:561342.

66. Abosi $\mathrm{AO}$, Raseroka $\mathrm{BH}$ : In vivo antimalarial activity of Vernonia amygdalina. Br J Biomed Sci 2003, 60(2):89-91.

67. Njan AA, Adzu B, Agaba AG, Byarugaba D, Diaz-Llera S, Bangsberg DR: The analgesic and antiplasmodial activities and toxicology of Vernonia amygdalina. J Med Food 2008, 11(3):574-581.

68. Iwalokun BA: Enhanced antimalarial effects of chloroquine by aqueous Vernonia amygdalina leaf extract in mice infected with chloroquine resistant and sensitive Plasmodium berghei strains. Afr Health Sci 2008 8(1):25-35.

69. Gachet MS, Lecaro JS, Kaiser M, Brun R, Navarrete H, Munoz RA, Bauer R, Schuhly W: Assessment of anti-protozoal activity of plants traditionally used in Ecuador in the treatment of leishmaniasis. J Ethnopharmacol 2010, 128(1):184-197.

70. Horgen FD, Edrada RA, de los Reyes G, Agcaoili F, Madulid DA, Wongpanich V, Angerhofer CK, Pezzuto JM, Soejarto DD, Farnsworth NR: Biological screening of rain forest plot trees from Palawan Island (Philippines). Phytomedicine 2001, 8(1):71-81.

71. Haddad M, Sauvain M, Deharo E: Curcuma as a parasiticidal agent: a review. Planta Med 2011, 77(6):672-678

72. Rasmussen HB, Christensen SB, Kvist LP, Karazmi A: A simple and efficient separation of the curcumins, the antiprotozoal constituents of Curcuma longa. Planta Med 2000, 66(4):396-398.

73. Nandakumar DN, Nagaraj VA, Vathsala PG, Rangarajan P, Padmanaban G: Curcumin-artemisinin combination therapy for malaria. Antimicrob Agents Chemother 2006, 50(5):1859-1860.

74. Aditya NP, Chimote G, Gunalan K, Banerjee R, Patankar S, Madhusudhan B: Curcuminoids-loaded liposomes in combination with arteether protects against Plasmodium berghei infection in mice. Exp Parasitol 2012 131(3):292-299.

75. Mishra K, Dash AP, Swain BK, Dey N: Anti-malarial activities of Andrographis paniculata and Hedyotis corymbosa extracts and their combination with curcumin. Malar J 2009, 8:26.

76. Toyang NJ, Verpoorte R: A review of the medicinal potentials of plants of the genus Vernonia (Asteraceae). J Ethnopharmacol 2013, 146(3):681-723.

77. Tabuti JR: Herbal medicines used in the treatment of malaria in Budiope county, Uganda. J Ethnopharmacol 2008, 116(1):33-42.

78. Challand S, Willcox M: A clinical trial of the traditional medicine Vernonia amygdalina in the treatment of uncomplicated malaria. J Altern Complement Med 2009, 15(11):1231-1237.

79. Phillipson JD, Wright CW, Kirby GC, Warhurst DC: Phytochemistry of some plants used in traditional medicine for the treatment of protozoal diseases. In International Symposium of the Phytochemical Society of Europe. Lausanne, Switzerland: University of Lausanne; 1993:3.

80. Kitagawa I, Mahmud T, Simanjuntak P, Hori K, Uji T, Shibuya H: Indonesian medicinal plants. VIII. Chemical structures of three new triterpenoids, bruceajavanin A, dihydrobruceajavanin A, and bruceajavanin B, and a new alkaloidal glycoside, bruceacanthinoside, from the stems of Brucea javanica (Simaroubaceae). Chem Pharm Bull (Tokyo) 1994, 42(7):1416-1421.

81. O'Neill MJ, Bray DH, Boardman P, Chan KL, Phillipson JD, Warhurst DC, Peters W: Plants as sources of antimalarial drugs, Part 4: Activity of Brucea javanica fruits against chloroquine-resistant Plasmodium falciparum in vitro and against Plasmodium berghei in vivo. J Nat Prod 1987, 50(1):41-48.

82. Kuo PC, Shi LS, Damu AG, Su CR, Huang CH, Ke CH, Wu JB, Lin AJ, Bastow $\mathrm{KF}$, Lee $\mathrm{KH}, \mathrm{Wu}$ TS: Cytotoxic and antimalarial beta-carboline alkaloids from the roots of Eurycoma longifolia. J Nat Prod 2003, 66(10):1324-1327.

83. Tandon VR: Medicinal uses and biological activities of Vitex negundo. Natural Product Radiance 2005, 4(3):162-165.

doi:10.1186/1472-6882-14-492

Cite this article as: Mohd Abd Razak et al: Effect of selected local medicinal plants on the asexual blood stage of chloroquine resistant Plasmodium falciparum. BMC Complementary and Alternative Medicine 2014 14:492 